різному. Нами розглянуто лише музично-культурологічні аспекти створення музичної продукції та можливі шляхи методологічного зближення культурологічних і музикознавчих розвідок.

\title{
Лiтература:
}

1. Leslie A. White. The Science of Culture: A Study of Man and Civilization. New York, Farrar, Straus and Cudahy, 1949.

2. Найдорф М. И. К исследованию понятия «музыкальная культура». Опыт структурной типологии // Наук. вісник Одеської держ. конс. ім. А. В. Нежданової. Зб. «Музичне мистецтво і культура». Вип. 1. - Одеса: Астропринт, 2000. - С. 46-51.

3. Конен В. Д. Третий пласт: новые массовые жанры в музыке ХХ века. - М.: Музыка, 1994. - 160 с.

4. Уайт Л. Избранное. Эволюция культуры. - М.: Российская политическая энциклопедия, 2004. - 1064 с.

DOI https://doi.org/10.30525/978-9934-26-004-9-84

\section{ФЛЕЙТА Й ЕЛЕКТРОННІ ТЕХНОЛОГІї: ЗВУКОЗАПИС, ОБРОБКА ТА ЕФЕКТИ ЗВУКУ}

\author{
Дуднік А. С. \\ студентка I курсу магістратури \\ факультету музичного мистецтвва \\ Харківської державної академії культури \\ м. Харків, Украӥна
}

При дослідженні взаємодії музичного мистецтва та сучасних технологій як одного з аспектів глобальних культурних трансформацій можна відзначити утворення феномену цифрових мистецтв, або арт медіа, для яких характерна інтерактивність, елітарність, нові художні засоби, форми i жанри. Розвиток технологій дає композиторам i виконавцям нові ідеї також для створення, запису, розповсюдження музики й тощо.

Для сучасного виконавця-флейтиста (як і будь-якого представника музичної професії) це має неабияке значення теж, особливо з огляду на пандемію і необхідність виступати дистанційно, за допомогою сучасних 
технологічних приладів. I тут є певні особливості, притаманні лише флейті (йдеться про сучасну поперечну флейту).

Оскільки флейта має невеликі динамічний і гармонічний діапазони, а саме - 261 Гц - до 2 кГц, час атаки -50 мс й не направлений звук, то іiі записувати досить не складно. Основні труднощі запису складають шум повітря, стук клапанів і чутне дихання виконавця. Запис, на якому $є$ шум від клапанів, неможливо обробити ефектом штучної реверберації, бо шум буде звучати більш близьким планом ніж звук самої флейти.

Спосіб запису відрізняється залежно від жанру і самої музики також.

Для запису класичної музики краще поставити мікрофон позаду голови виконавця. Це мінімізує всі раніше перераховані складності запису. Приміщення слід підбирати відповідно до стилю музики, наприклад, невелике приміщення 3 природною реверберацією для салонних творів, або великий зал для оркестрових і т.д. Для «повітряної» музики типу «Мелодії» Глюка мікрофон краще поставити подалі від музиканта [1].

Під час виконання естрадної музики, де флейта грає ритмічну роль, а музикант підспівує або використовує прийоми біт-боксу, мікрофон зручніше поставити навпроти виконавця і використати поп-фільтр, щоб уникнути «задування» мікрофону.

Іноді досягнення гарного результату передбачає використання нестандартних рішень, у тому числі експерименти з мікрофоном і його положенням, або з приміщенням. Наприклад, записати флейту всередині вулканічної печери як Nicola Cruz - Arka (con Esteban Valdivia).

Партію флейти також можна набрати в спеціальній DAW програмі (VST- плагін, імітуючий звук флейти) або зіграти на синтезаторі. Та $\epsilon$ один мінус - ці способи не передають плавного затухання/роздування ноти як на справжній флейті. Проблему вирішує використання електронного саксофону, який відтворює різні тембри, у тому числі й флейти (але він є досить рідкісним інструментом), або семплу заздалегідь записаного фрагменту мелодії.

Ефекти і обробка звуку:

Реверберація (Reverb) - ефект, заснований на додаванні до вихідного сигналу серії його затухаючих та затриманих у часі копій, що імітує відлуння звуку в приміщенні [3, с. 98]. Складністю усіх духових є гра на legato (через принцип переходу з ноти на ноту), тож ефект відлуння згладжує і прикрашає звучання. Тим паче, жива гра також передбачає відлуння в залі.

Ділей (Delay) - ефект затримки звуку з подальшим його відтворенням (один чи декілька разів) через певний період часу. Схожий на чітке 
затухаюче відлуння. Відрізняється від реверберації більш великим часом затримки, більше ніж 50-60 мс. Також гарно поєднується зі звуком флейти, роблячи звучання загадковим, атмосферним, космічним.

Зворотна реверберація - ефект наростання. Реверс (перевертання задом наперед) запису обробляється ефектом реверберації або іншим ефектом затримки звуку, потім повертається в початкове положення.

Хорус (Chorus) - імітує хор людей чи інструментів.

Еквалайзер (Equalize - «вирівнювати», «ЕQ») - регулює гучність звуку в залежності від його висоти. Крайні діапазони на флейти мають свої особливості: високі ноти складно зіграти на піано, а низькі звучать навпаки тихо. Їх можна вирівняти за гучністю користуючись еквалайзером.

Компресія (від англ. «compress» - стискати, здавлювати) автоматична регуляція динаміки звуку. Робить голосний звук тихіше, а тихий навпаки голосніше, що дозволяє «виділити», «ущільнити», «вирівняти» звук та акцентувати атаку інструменту.

Зміна форманти звуку - зміна тембру на більш низький або високий без зміни висоти ноти. Додає нових фарбів звучанню флейти.

Зміна «пітчу» (pitch - висота звуку) - часто використовують для виправлення фальшивого вокалу. На флейті, наприклад, можна створити звуки нижче існуючого діапазону інструмента.

Гармонайзер (Harmonizer) - створює нову партію в октаву, унісон, терцію, в залежності від алгоритму.

Шумопониження або Gate - допоможе знизити шум від клапанів, дихання, повітря, апаратури, а також випадковий шум, який потрапив на запис.

Сатурація (Saturation) - це ефект насичення сигналу гармонічними коливаннями. Помірна присутність сприяє поліпшенню сприйняття звуку. Звучання флейти з додаванням ефекту сатурації можна описати як тепліше, більше, ближче, чистіше, яскравіше.

Дисторшн (distortion) - навмисне спотворення звуку, що надає йому різкий, скреготливий відтінок [3, с. 99]. Спочатку це був лише гітарний ефект, який використовували в рок-музиці. Але зараз їм обробляють навіть вокал. Звук флейти $з$ цим ефектом схожий на звук електрогітари 3 педаллю distortion, який проте зберігає характер звучання флейти. Також можна регулювати рівень спотворення звуку й отримати різні результати.

Фленжер (flanger) - використовується для створення настрою присутності істот потойбічних світів. Він чудовий для створення ефекту перебування під водою [2, с.78]. 
Фейзер (phaser) - дуже тонкий і підступний ефект. Так, будучи використаний на концертах Greatful Dead, натовп уявляла, що він виходить зсередини їх мозку [2, с.78]. Фленжер і фейзер досить складно поєднуються зі флейтою, але вони $є$ незамінні коли треба отримати певне психоделічне звучання.

Також існують способи застосування ефектів у реальному часі, наприклад, на концерті, користуючись спеціальним обладнанням. Використовуючи ефекти та способи обробки звуку можливо досягти нового звучання флейти, або переосмислити та покращити класичне.

\title{
Література:
}

1. Все про професійний звук [Електронний ресурс] // All Pro Sound. 2015. - Режим доступу до ресурсу: http://www.allprosound.ru/about/

2. Гібсон Д. ; під. ред. Петерсона Г. «Мистецтво зведення». Візуальне керівництво зі звукозапису і продюсування / Д. Гібсон., 2007.

3. Ракунова I. Н. Нові композиторські технології. Творчість Алли Загайкевич. / І. Н. Ракунова. - Київ: Фенікс, 2010.

DOI https://doi.org/10.30525/978-9934-26-004-9-85

\section{ЗНАК І СИМВОЛ - ПІКТОГРАМИ КРІЗЬ СТОЛІТТЯ: СОЦІОКУЛЬТУРНЕ ТА ПРИКЛАДНЕ ЗНАЧЕННЯ}

\author{
Дядюх-Богатько Н. Й. \\ кандидат мистецтвознавства, доиент, \\ завідувач кафедри \\ Української академії друкарства \\ м. Львів, Украӥна
}

Графічні символи крізь тисячоліття виринають від наших прапрадідів на стінах печер, кам'яних стелах по степах, керамічних рештках археологічних культур, як написи-орнаменти на зброї, архітектурних вцілілих рештках та на пізніших носіях історичної пам'яті - папері. Видряпані гострими предметами чи намальовані вохрою давні графічні символи могли містить солярні, зооморфні, антропоморфні зображення, поєднання яких розгадують наші вчені. Хоч для сучасників ці графеми несли цілком реальний комунікативний посил.

Перехід поодиноких символічних знаків до низки їх поєднань вважають наступним кроком для низки гіпотез. Це ще можна прирівняти 68 